\title{
Hydrogeological Study of the Groundwater Aquifers in the Reclamation Area of the Desert Fringes East Nile between Biba - El Fashn, Eastern Desert, Egypt
}

\author{
El Sayed Ali El Sayed El Abd \\ Geology Department, Desert Research Center, Cairo, Egypt,
}

\section{A R T I C L E I N F O}

Article history:

Received 29 October 2015

Accepted 09 January 2016

Keywords:

Hydrogeology;

Geomorphology;

Biba El-Fashn area;

Middle Eocene aquifer;

Eastern Desert fringes;

Egypt.

\begin{abstract}
A B S T R A C T
Development of the Nile Desert fringes and establishing of new communities and settlements are among the future national plans of Egypt. East Biba - El Fashn area represents one of the interesting areas for the future land reclamation. Geomorphologically, the study area is classified into; recent Nile alluvial plain, limestone plateau, structural ridges and drainage network. Middle Eocene (Mokattam group) is the oldest exposed rock units. It is classified into; Qarara, observatory and Beni Suef formations. The groundwater is available in the lower part of El Fashn F. (limestone with chert and Nummulites) and the upper part of Qarara F. (limestone, siltstone and marl). The groundwater is recorded at depths ranged from $6 \mathrm{~m}$ to $82.2 \mathrm{~m}$ and their salinities are ranged from $5932 \mathrm{mg} / \mathrm{l}$ to 256 $\mathrm{mg} / \mathrm{l}$. Groundwater is recharged from Nile water of the irrigation canals in the western part of the study area and from the occasional shores rain in the eastern one. Transmissivity values range from $782.5 \mathrm{~m}^{2} /$ day (in the western part of the study area) to $0.55 \mathrm{~m}^{2} /$ day (in the eastern part). Aquifer potentialities range from high to very low potentiality. The variation in transmissivity and potentiality are attributed mainly to the fractures density. Nile water and 25 groundwater samples were collected, chemically analyzed and evaluated. The major elements are determined and their geneses are suggested.
\end{abstract}

\section{Introduction}

Establishing of new communities and settlements in the eastern desert fringes of the Nile Valley are among the ambitious national plans. Proper and successful programs for water resources evaluation are urgently required. Beni Suef governorate occupies one of the concerned areas, where the water bearing formations have a wide geographical distribution and differ greatly in their extension, potentialities and source of recharge. Only the Middle Eocene aquifers are recorded in the study area. East Biba - El Fashn area lies east of the Nile valley, southeast Beni Suef City. It is bounded from west by the River Nile, from south by Wadi Ash-Shaykh and from north and west by Wadi Sannur. It lies between longitudes $30^{\circ} 54^{\prime} \mathrm{E}$ and $31^{\circ} 10^{\prime} \mathrm{E}$ and latitudes $28^{\circ} 48^{\prime} \mathrm{N}$ and $28^{\circ} 56^{\prime} \mathrm{N}$ (Fig. 1).

The area is characterized by scarce rainfall and high evaporation internists. The meteorological data reflect annual total rainfall of $7.8 \mathrm{~mm} /$ year, mean monthly evaporation ranges from $170.5 \mathrm{~mm} /$ month (Jan.) to

* Corresponding author.

E-mail address: elsayedelabd@hotmail.com

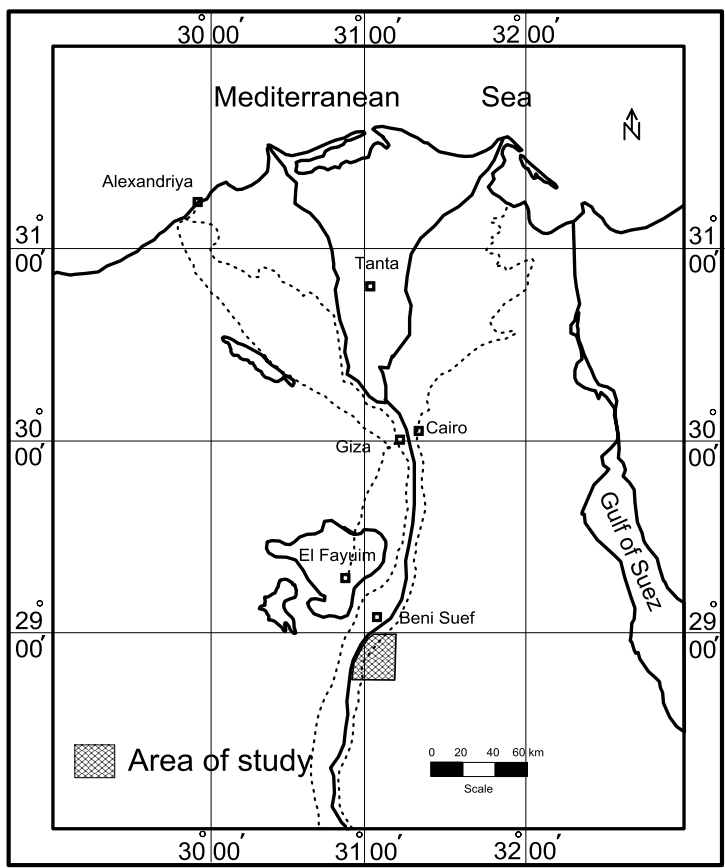

Fig. 1: Location map of the study area 
$603 \mathrm{~mm} /$ month (June) and mean relative humidity ranges from $43 \%$ (Jul.) to $57 \%$ (Nov. and Dec.). The mean daily temperature ranges from $12.2^{\circ} \mathrm{C}$ (Jan.) to $29.1{ }^{\circ} \mathrm{C}$ (Jul.). Heavy storm showers of occasional rainfall were recorded once per 3, 5 or 7 years along the Eastern Desert. They contribute the area by great amount of water and recharge the groundwater aquifers in the dray vallies as well as they provide heavy flash floods of very short periods.

The present study is focused on the following topics:

- Investigation of the main geomorphologic and geologic features, which affect the hydrogeologic setting.

- Hydrogeological investigation of the existed water points.

- Investigation of the hydrogeochemical properties of the groundwater and determining its suitability for drinking and irrigation uses.

\section{Geomorphologic features}

The Study area exhibits different topographic features reflecting the impacts of geologic and climatic processes affecting the area in the last periods. Using the topographic maps (scale 1:50,000), the geologic maps (scale 1:250,000) and the field investigation, the area of study is distinguished into the following four main geomorphic units (Fig. 2):

1- Recent Nile alluvial plain: It is occupied by the cultivated lands and urban villages bordering the eastern side of the Nile. It is a narrow strip parallel to the River Nile. Its width varies from $2 \mathrm{~km}$ opposite delta Wadi
Ghayyudah and El Fashn city to less than $1 \mathrm{~km}$ at the rest of the plain. Its ground elevation ranges between $40 \mathrm{~m}$ above sea level in the east to $30 \mathrm{~m}$ close to River Nile.

2- Limestone plateau: It represents the eastern fringes of the Nile valley. It slopes towards the north and west. It has an elevation higher than the flood plain and varies from about $40 \mathrm{~m}$ to about $100 \mathrm{~m}$. It is built of Eocene limestone covered by drift sands, flints, gravel with black to dark brown color and boulders of carbonate. Many drainage lines dissect this plateau and drain into River Nile westward. The eastern desert fringes occupy the strip of land lying close to the flood plain and the foot scarps of the plateau.

3- Structural ridges: They occupy the higher parts of the limestone plateau and the major are representing at the south eastern part of the plateau. They form three parallel ridges in the north western direction. These ridges from north to south are; G. al Mashash (165 m) G. UmRaqhabah $(127 \mathrm{~m})$ ridge, Ras Umm Al-hawayah $(317 \mathrm{~m})$ - G. al-Hadid $(252 \mathrm{~m})$ ridge and G. al-Abyad (255 m) - G. Umm Al-hawayah (245 m) ridge, They are built of Eocene limestone. They are characterized by ground elevation ranging from $317 \mathrm{~m}$ above sea level to $127 \mathrm{~m}$ above sea level.

4-Drainage network: It consists of several drainage basins that drain westward into the River Nile and its flood plain in the west. They have NW - SE direction. They affected by the dominant NW-SE fracture system. The main basins are from north to south; W. Sannur, W. Ghayyudah and W. Al-Faqirah.

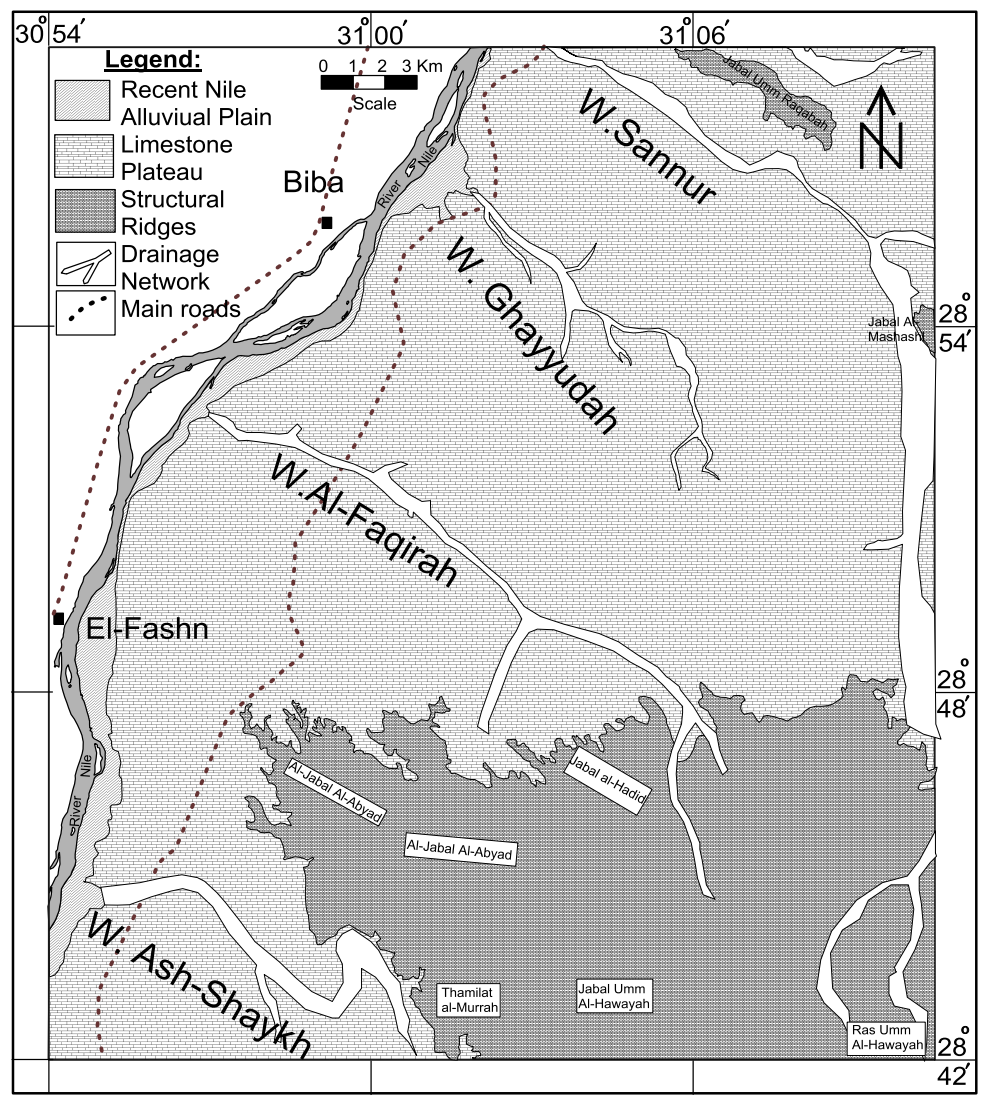

Fig. 2: The main geomorphic units of Biba-El Fashn area. 


\section{Geologic setting}

The studied area represents a portion of the eastern bank of the River Nile. The geological conditions play an important role in determining the geomorphic setting and the hydrogeological characteristics. The geologic setting of the study area is discussed through two main items; the stratigraphic succession and the structural lineaments:

\section{Stratigraphic succession}

The surface of the studied area is built up of different rock units ranging in age from Middle Eocene (Mokattam group) to Quaternary deposits ${ }^{[1]}$, Fig. (3).

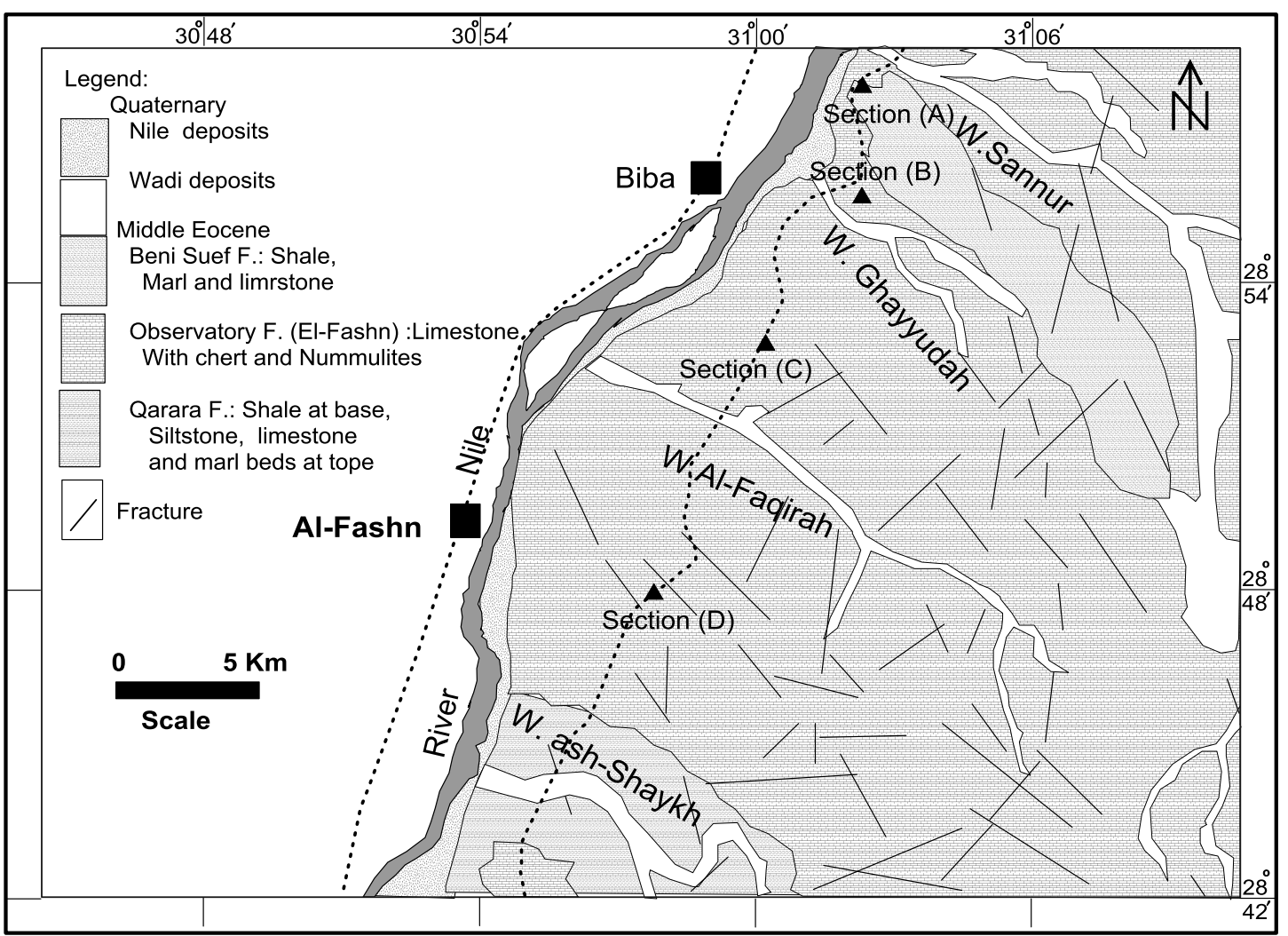

Fig. 3: Geologic map of Biba-El Fashn area ${ }^{[1]}$

The exposed rock units are discussed from base to top as follows:

Middle Eocene (Mokattam group): It is distinguished in the study area into three formations; Qarara, observatory and Beni Suef.

a) Qarara Formation:

The term Qarara Formation was introduced by ${ }^{[2]}$ for the Middle Eocene sequence (Upper Lutetian age) east of Maghagha at G. Qarara. It has a thickness of $170 \mathrm{~m}$. thick and is composed of shale, marl, sandstone and sandy limestone.

The Qarara Formation at Beni Suef area is characterized by fractures, partings veins, veinlets and geodes filled with calcite. Subsurface caves were developed along the intersection of fractures. They are detected during the deepening of the surface quarries having longitudinal shape with ideal stalactites and stalagmites ${ }^{[3]}$.

b) Observatory Formation (El-Fashn Formation):

It was defined in most of the exposed section lying east and west of Beni Suef area. Its maximum thickness (90 $\mathrm{m}$. thick) was described by ${ }^{[4]}$ in a section lying west of Beni Suef. The term El-Fashn Formation in the stratigraphy of the Nile Valley was introduced by ${ }^{[2]}$ for a rock sequence exposed at wadi El sheikh, east of Biba and at G. Umm Raqaba lying south east of Beni Suef. It is distinguished by different facies, since it is built up of chalky limestone with chert bands or nodules followed upward by green shales with gypsum veinlets at Wadi El sheikh.

Three surface sections were measured for Observatory Formation (Figs. 3 and 4). The first section is located south W. Ghayyudah (Section B) and composed of $70 \mathrm{~m}$ limestone; pale yellow, very hard, highly fossiliferous, cavernous and fractured. Carbonates \% are from 98.9 to 99.8 and clastics $\%$ are from 1.1 to 0.2 . The second section is located north W. Al-Faquirah (Section C) and composed of $55 \mathrm{~m}$ limestone; pale brown, very hard, highly fossiliferous, cavernous and fractured, ferruginous at top. The carbonates \% are from 96.4 to 99.8 and clastics $\%$ are from 3.6 to 0.2 . The third section is located at G. Abyad (Section D) and composed of $42 \mathrm{~m}$ limestone; pale grey, very hard, highly fossiliferous, cavernous and fractured. The carbonates \% are from 96.1 to 97.9 and clastics \% are from 3.9 to 2.1 . 
C) Beni Suef Formation:

The term "Beni-suef Formation" was also introduced by

${ }^{[2]}$. Its maximum thickness was described by ${ }^{[4]}$ at Gabel Sath El-Hadid lying west of Beni-Suef area $(100 \mathrm{~m}$ thick) ${ }^{[5]}$ subdivided the Beni-Suef Formation into two members; Qurn Member at the base topped by Tarbul Member. Strougo et al. ${ }^{[6]}$ described the Beni-Suef Formation to be equivalent to the upper part of the Lower Mokattam Formation for the sequence which is well exposed at G. Umm Raqaba, east of Beni-Suef (45m thick).

Beni Suef Formation is made of thick-bedded argillaceous limestone interbedded with clay. Its upper part is composed of laminated clay unit (25-30m thick) and ends with a wall-forming thin bedded argillaceous limestone unit rich in Lucinia sp. (12m thick). The BeniSuef Formation contains Nummulites, Turritellasp, Gastropod molds and vertebrate bones.

The measured exposed thickness of Beni Suef Formation at G. Al Nur (the western portions of Wadi Sannur, Section A) is about $22 \mathrm{~m}$ clay; yellowish grey, gypsiferous. Carbonates - clastics \% are 34.2 and 65.8 respectively.

Quaternary deposits: The Quaternary deposits cover large areas of the surface of the study area and it is represented by the following deposits:

i- Nile deposits; cover the area adjacent to the River Nile. It is composed mainly of mud and fine sand. They form a narrow strip and are considered the old cultivated lands.

ii-Wadi deposits; formed mainly of silt, sand and gravel representing the weathering product of the country rocks. Fanglomerates are exposed at the downstream portions of W. Ghayyudah and W. Al-Faqirah and consist mainly of limestone fragments. Drift sand and gravels cover the inland depressions at the downstream portion of W. Al-Faqirah.

\section{Structural Lineaments}

The geologic map ${ }^{[1]}$ and field investigations indicate the structural lineament setting (Fig. 3). The structural lineaments of the study area are controlled mainly by the structural setting of the Red Sea and the Gulf of Suez (NW - SE) and Syrian Arc system (NE - SW) beside the rocks types which cover the surface area.

Rose diagram of the structural lineaments analysis of the different wadis in the study area (Fig. 5) clear the following topics:

- Wadi Sannur was affected by 9 structural lineaments with $23.86 \mathrm{~km}$ lengh. The dominant lineament direction is N10-20W with dominant number, followed by N10-20E, followed by N20-30W. It has a structural density of $0.068 \mathrm{~km} / \mathrm{km}^{2}$

- Wadi Al-Faqirah was affected by 30 structural lineaments with $81.55 \mathrm{~km}$ lengh. The dominant lineament direction is $\mathrm{N} 30-40 \mathrm{~W}$ with dominant number, followed by N40-50W, followed by N0-10E. It is characterized by structure density of $0.15 \mathrm{~km} / \mathrm{km}^{2}$ and they are intersected

- Wadi Ghayyudah was affected by 6 structural lineaments with $11.57 \mathrm{~km}$ lengh. The dominant lineament direction is N40-50E, followed by N10$20 \mathrm{~W}$ with dominant number, followed by N40-50W. It has a structure density of $0.094 \mathrm{~km} / \mathrm{km}^{2}$

It becomes obvious that $\mathrm{W}$. Al-Faqirah has the highest number, length and density of structural lineaments. The next grad is W. Sannur and W. Ghayyudah.
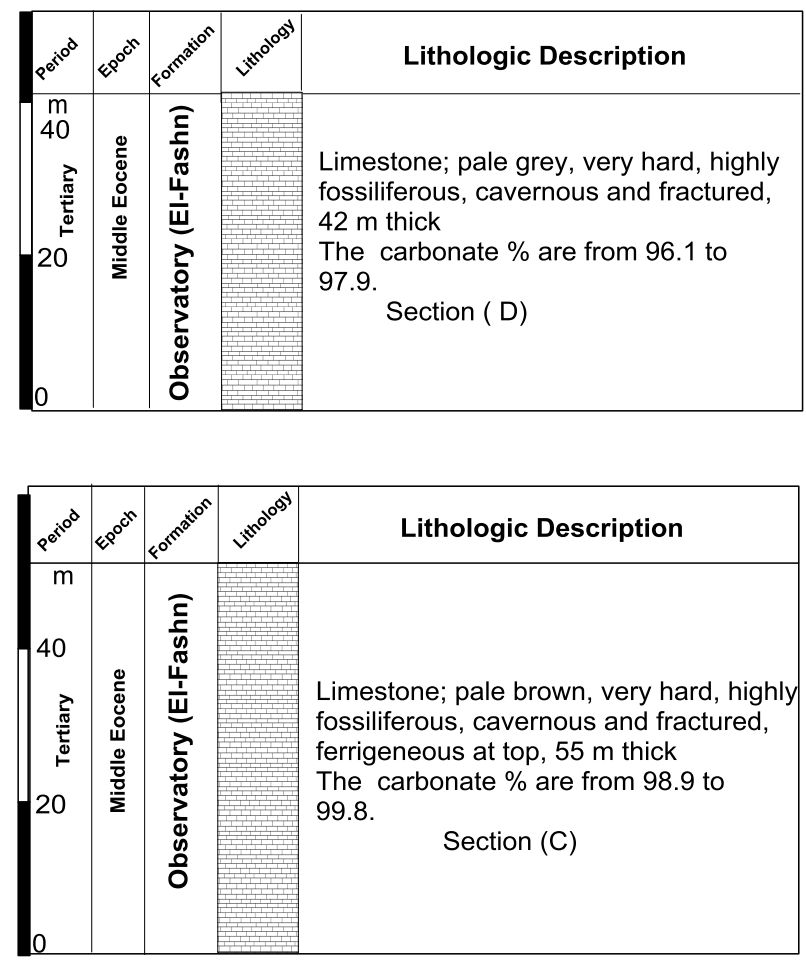
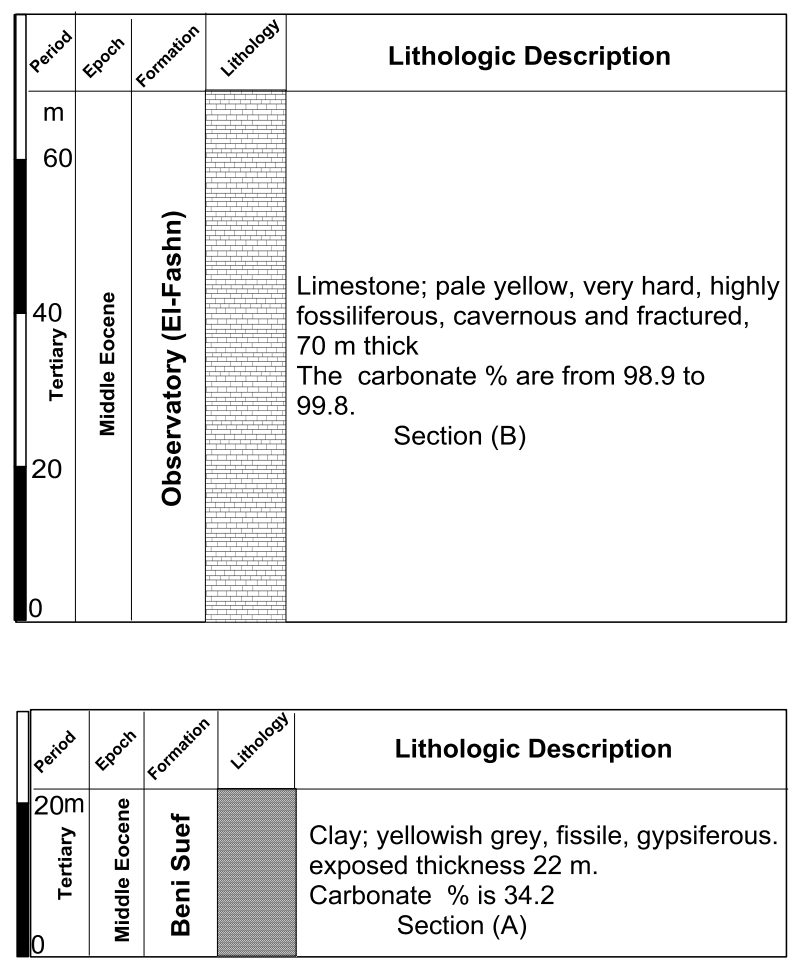

Fig. 4: Surface geological sections of Biba-El Fashn area. 


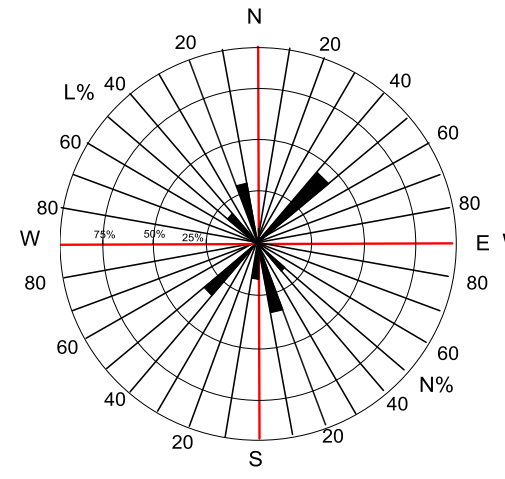

W. Ghayyudah

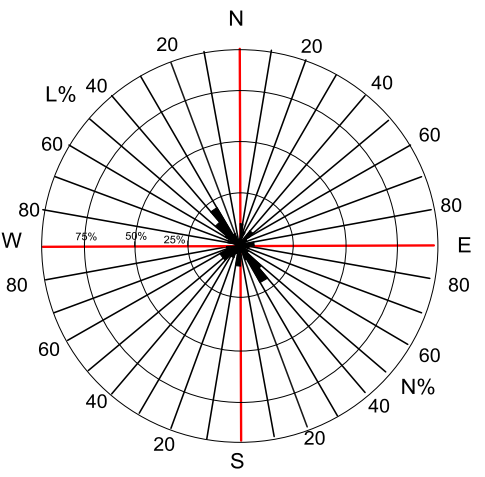

W. Al-Faqirah

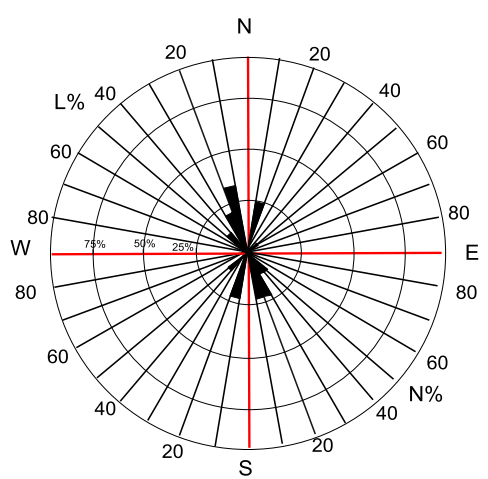

W. Sannur

Fig. 5: Azimuth-Frequency diagrams of the structural lineaments of Biba - El-Fashn area.

\section{Hydrogeologic conditions}

The groundwater of Biba - El Fashn area is recorded only in the Middle Eocene limestone aquifer. Some studies concerning the hydrogeology of the study area were carried out, among them are; [7-11]. The hydrogeological study depends on the obtained data of 25 open hall drilled wells by the personal communication of the local peoples (Fig. 6 \& Table 1). The rock forming the aquifers is composed of the chalky limestone with chert bands or nodules of the lower part of El Fashn Formation and the sandstone and sandy limestone of the upper part of Qarara Formation. The concerned aquifers are recharged mainly by the Nile water of the irrigation canals in the western part and by the occasional storm rainfall in the eastern part through the fracture systems.

The depth to water ranges from $82.2 \mathrm{~m}$ (well no. 16) to 6 $\mathrm{m}$ (well no. 21) and the total depth ranges from $234 \mathrm{~m}$ (well no. 25) to $15 \mathrm{~m}$ (well no. 21). The groundwater salinity of the concerned aquifer ranges from $5932 \mathrm{mg} / \mathrm{l}$ (well no. 2) to $256 \mathrm{mg} / \mathrm{l}$ (well no. 21). The high salinity of the water of the concerned aquifers is mainly attributed to the little recharge and presence of shale beds within the aquifer water bearing rocks.

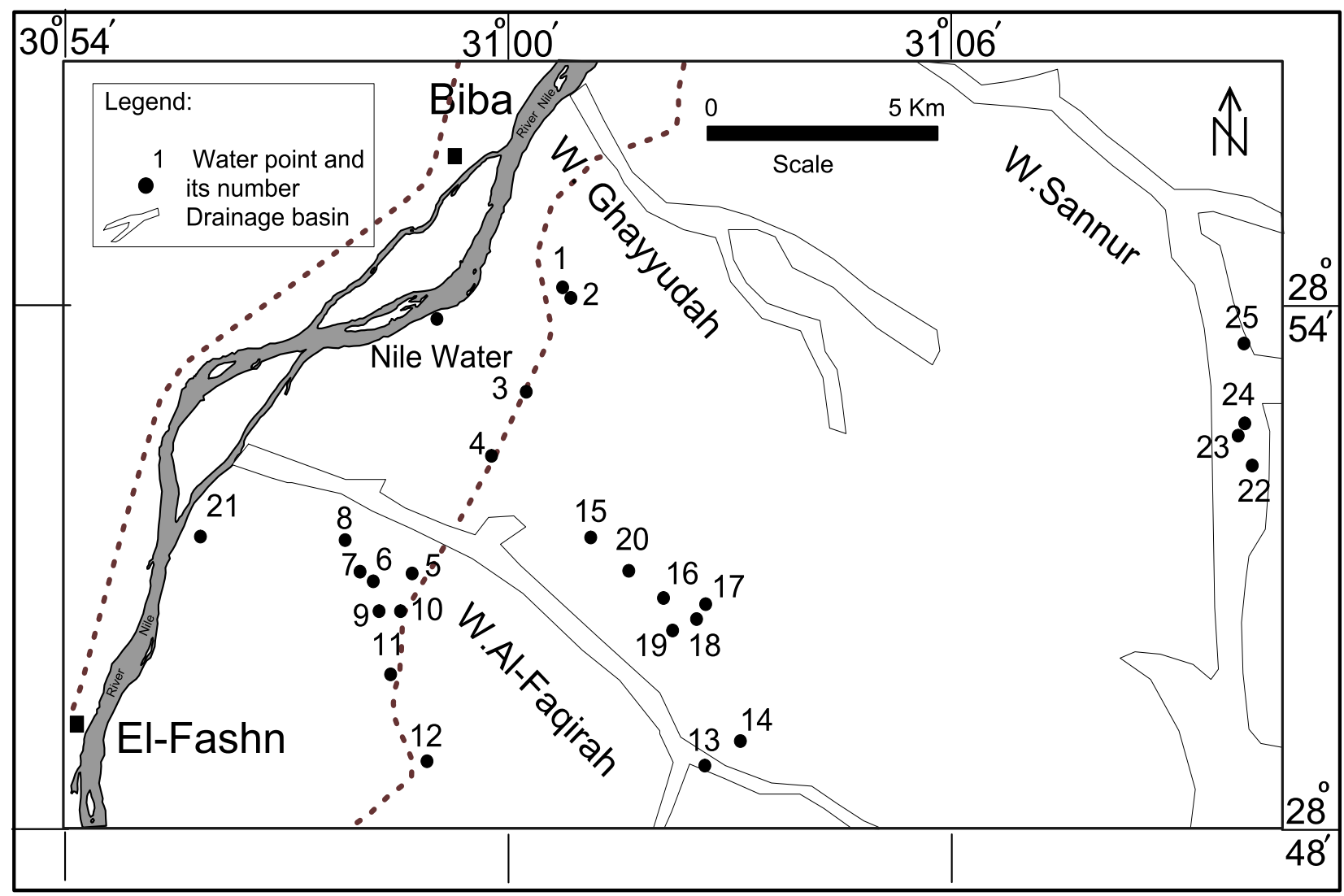

Fig. 6: Well location map of Biba - El-Fashn area. 
Table 1: Hydrogeological data of the studied aquifers.

\begin{tabular}{|c|c|c|c|c|c|c|c|c|c|}
\hline $\begin{array}{c}\text { Sample } \\
\text { No. }\end{array}$ & $\begin{array}{l}\text { Latitude } \\
\text { (Degree) }\end{array}$ & $\begin{array}{l}\text { Longitude } \\
\text { (Degree) }\end{array}$ & $\begin{array}{c}\text { Location } \\
\text { (Drainage } \\
\text { basin) }\end{array}$ & Aquifer & $\begin{array}{c}\text { Total } \\
\text { depth } \\
(\mathbf{m}) \\
\end{array}$ & $\begin{array}{c}\text { Depth to } \\
\text { Water } \\
\text { (m) } \\
\end{array}$ & $\begin{array}{c}\text { Ground } \\
\text { elevation } \\
\text { (m) } \\
\end{array}$ & $\begin{array}{c}\text { Water } \\
\text { level } \\
\text { (m.a.s.l) } \\
\end{array}$ & $\begin{array}{c}\text { Salinity } \\
\text { (ppm) }\end{array}$ \\
\hline 1 & 28.90306 & 31.01244 & \multirow{2}{*}{$\begin{array}{l}\text { North W. } \\
\text { El Faquirah }\end{array}$} & \multirow{25}{*}{$\stackrel{0}{0}$} & 150 & 45 & 75 & 30 & 3663.20 \\
\hline 2 & 28.90156 & 31.01408 & & & 150 & 47.3 & 77 & 29.7 & 5932.00 \\
\hline 3 & 28.88444 & 31.00442 & \multirow{19}{*}{ 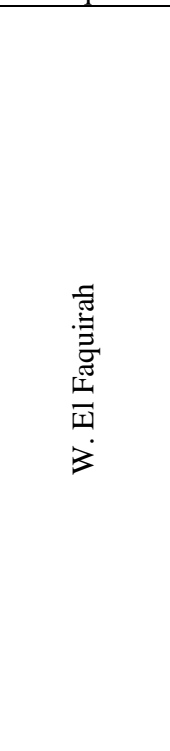 } & & 150 & 46.7 & 73 & 26.3 & 2340.75 \\
\hline 4 & 28.87078 & 30.99667 & & & 210 & 52.3 & 78 & 25.7 & 3946.69 \\
\hline 5 & 28.84847 & 30.97914 & & & 150 & 54.42 & 80 & 25.58 & 2056.66 \\
\hline 6 & 28.84731 & 30.96925 & & & 150 & 55.1 & 81 & 25.9 & 1748.89 \\
\hline 7 & 28.84917 & 30.96723 & & & 150 & 54.8 & 81 & 26.2 & 2508.80 \\
\hline 8 & 28.85481 & 30.96306 & & & 150 & 48.2 & 75 & 26.8 & 1448.32 \\
\hline 9 & 28.84106 & 30.97114 & & & 160 & 64.2 & 90 & 25.8 & 1984.00 \\
\hline 10 & 28.84139 & 30.9755 & & & 160 & 56.5 & 82 & 25.5 & 1900.80 \\
\hline 11 & 28.82906 & 30.97356 & & & 120 & 69.5 & 95 & 25.5 & 914.56 \\
\hline 12 & 28.81228 & 30.98186 & & & 120 & 79 & 104 & 25 & 2105.60 \\
\hline 13 & 28.81236 & 31.04503 & & & 192 & 80 & 106 & 26 & 1521.92 \\
\hline 14 & 28.81664 & 31.05236 & & & 195 & 80.8 & 108 & 27.2 & 1367.04 \\
\hline 15 & 28.85517 & 31.01908 & & & 170 & 73.5 & 96 & 22.5 & 2067.20 \\
\hline 16 & 28.84458 & 31.03569 & & & 180 & 82.2 & 101 & 18.8 & 700.16 \\
\hline 17 & 28.84278 & 31.04514 & & & 180 & 81 & 101 & 20 & 575.36 \\
\hline 18 & 28.83975 & 31.04358 & & & 190 & 78.3 & 98 & 19.7 & 552.32 \\
\hline 19 & 28.8375 & 31.03708 & & & 180 & 81.8 & 101 & 19.2 & 810.88 \\
\hline 20 & 28.84906 & 31.02797 & & & 180 & 75.5 & 96 & 20.5 & 1110.40 \\
\hline 21 & 28.85564 & 30.93092 & & & 15 & 6 & 38 & 32 & 256.00 \\
\hline 22 & 28.869 & 31.16739 & \multirow{4}{*}{ 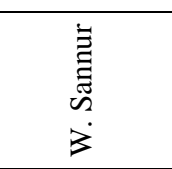 } & & 100 & 29.8 & 91.04 & 61.24 & 3579.00 \\
\hline 23 & 28.87578 & 31.16528 & & & 100 & 27.17 & 90.75 & 63.58 & 4581.00 \\
\hline 24 & 28.877 & 31.16597 & & & 70 & 25.4 & 88.23 & 62.83 & 5293.50 \\
\hline 25 & 28.89281 & 31.16597 & & & 234 & 21.01 & 83.27 & 62.26 & 3442.50 \\
\hline Nile water & 28.89786 & 30.98314 & River Nile & & & & & 31 & 233.38 \\
\hline
\end{tabular}

The constructed hydrogeological cross sections $\mathrm{A}-\mathrm{A}^{\prime}$ and B - B' (Fig 7) reveal the followings:

-Cross section $\mathrm{A}-\mathrm{A}^{\prime}$ reveals that, the study area from northeast to southwest affected by a group of faults with downthrown sides towards $\mathrm{NE}$ and SW directions forming major grabben in the middle of the study area (Fig. 7). These faults, bring Beni Suef Formation (Shale, marl with limestone interbeds) in the north and Qarara Formation (shale at base, siltstone, marl and limestone at top) in the south, opposite El-Fashn Formation (Limestone with chert and Nummulites) water bearing formation. Shale and marl of Beni Suef and Qarara Formations are considered a barrier of groundwater recharge and reduce groundwater recharge.

-Cross section $\mathrm{B}-\mathrm{B}^{\prime}$ reveals that, the study area from west to east affected by a group of faults with downthrown sides towards SE and SW directions forming major grabben in the middle of the study area. These faults blocks, bring Qarara Formation in the east at high level opposite to El-Fashn water bearing formation and influence the hydraulic heads of the aquifer. This situation reduces the saturated thickness of the water bearing formation at the east and separating the aquifer in Wadi Sannur from the rest of the aquifer in the west. So it prevents groundwater recharge from River Nile in the west. So groundwater recharge from River Nile is restricted to the western part of the study area lying close to the Nile.
Water level map (Fig. 8), indicates two patterns of groundwater flow:

-in the western part of the study area; the groundwater flow is mainly from west and northwest to east and southeast, i.e. The irrigation canals are the main source of recharge. The groundwater levels range from 31 m.a.s.l. at west (Irrigation canals) to 18.8 m.a.s.l. (well no. 16).

-in the eastern part of the study area; the groundwater flow is mainly from east to west, i.e. an occasional heavy showers once per 3, 5, 7 years is the main source of recharge. The groundwater levels range from 63.58 m.a.s.l. at east (well no. 23) to 18.8 m.a.s.l. at west (well no. 16). The groundwater of the aquifer in the east (in Wadi Sannur) is located at higher level than the rest of the aquifer in the west

For evaluating the hydraulic parameters of the limestone aquifer in Biba - El-Fashn area, four pumping tests (constant discharge pumping and recovery), were operated for four wells distributed over the area of the concerned aquifer. Jacob ${ }^{[12]}$ and Cooper and Jacob ${ }^{[13]}$ methods were applied for the analysis of the obtained data of pumping test, as follows (Fig. 9):

-Transmissivity of the water bearing rocks is estimated according to the following equation:-

$$
\mathrm{T}=2.303 \mathrm{Q} / 4 \pi \Delta \mathrm{s}\left(\mathrm{m}^{2} / \text { day }\right)
$$

Where $\mathrm{Q}$ : is the rate of the discharge in $\mathrm{m}^{3} /$ day

$\Delta \mathrm{s}$ : is the drawdown difference per log cycle of time. 

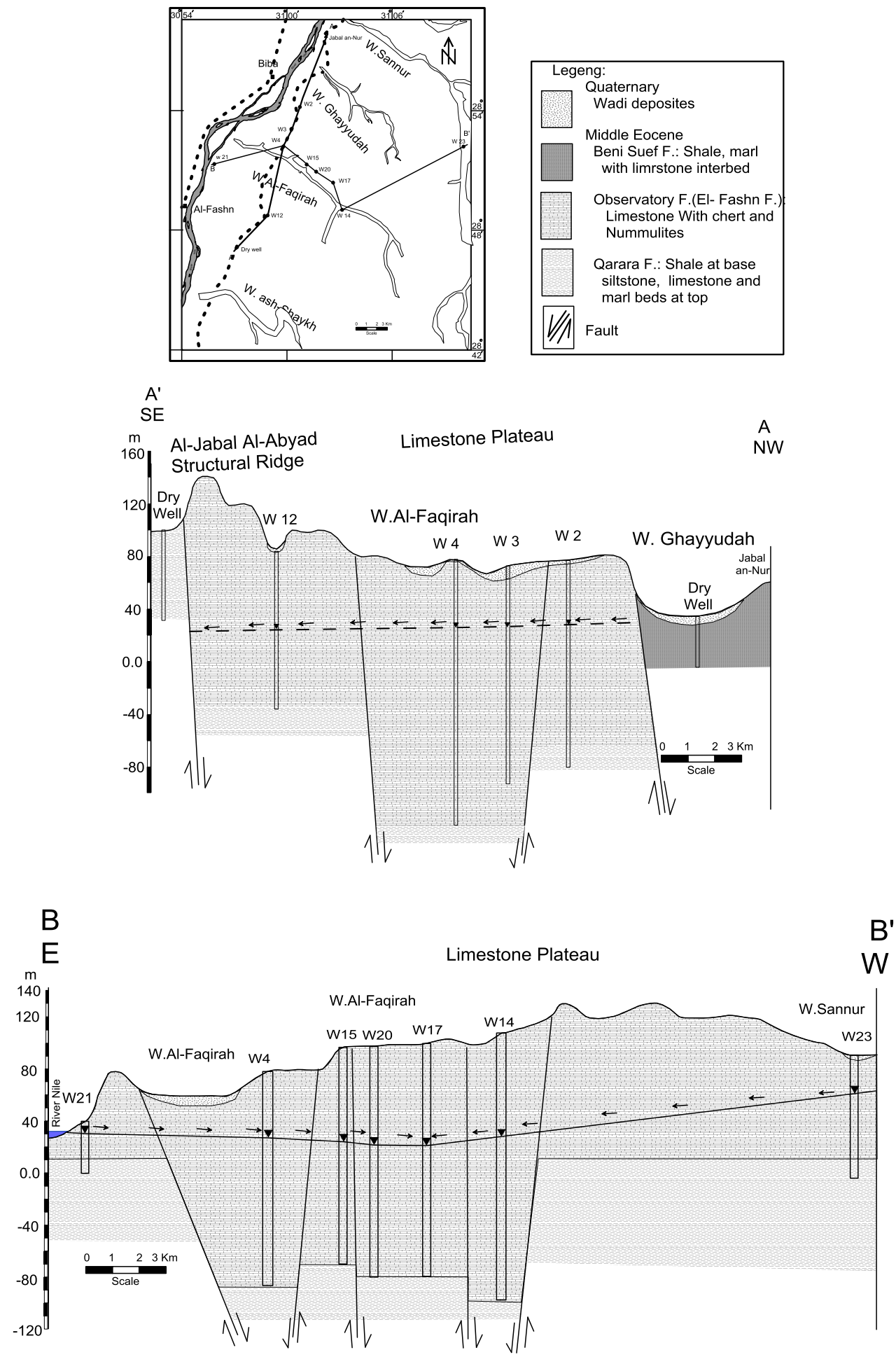

Fig. 7: Hydrogeological cross sections of Biba - El-Fashn area.

The calculated Transmissivity values ranges from 989.5 $\mathrm{m}^{2} /$ day (well No. 9; in the western part of the study area) to $0.413 \mathrm{~m}^{2} /$ day (well No. 20 ; in the eastern part of the study area).

During the recovery method test ${ }^{[14]}$, the slope of the line of best fit, per one log cycle $\left(\Delta s^{\prime}\right)$ is determined. Transmissivity $(\mathrm{T})$ is determined using the following equation:-

$$
\mathrm{T}=2.3 \mathrm{Q} / 4 \pi \Delta \mathrm{s}^{\prime}
$$

Where $\mathrm{Q}$ is the rate of discharge $\left(\mathrm{m}^{3} /\right.$ day).
$\Delta \mathrm{s}^{\prime}$ is the depth to water during recovery-initial static water level.

(residual drawdown difference per log cycle of time).

The calculated transmissivity values range from 574.9 $\mathrm{m}^{2} /$ day (well No. 9) to $0.675 \mathrm{~m}^{2} /$ day (well No. 20). According to ${ }^{[15]}$ classification; it ranges from high to Negligible or very low potentiality (Table 2). The variation in transmissivity values is attributed mainly to the fractures density which reflects anisotropic and heterogenic fractured carbonate aquifers (Fig. 5). 


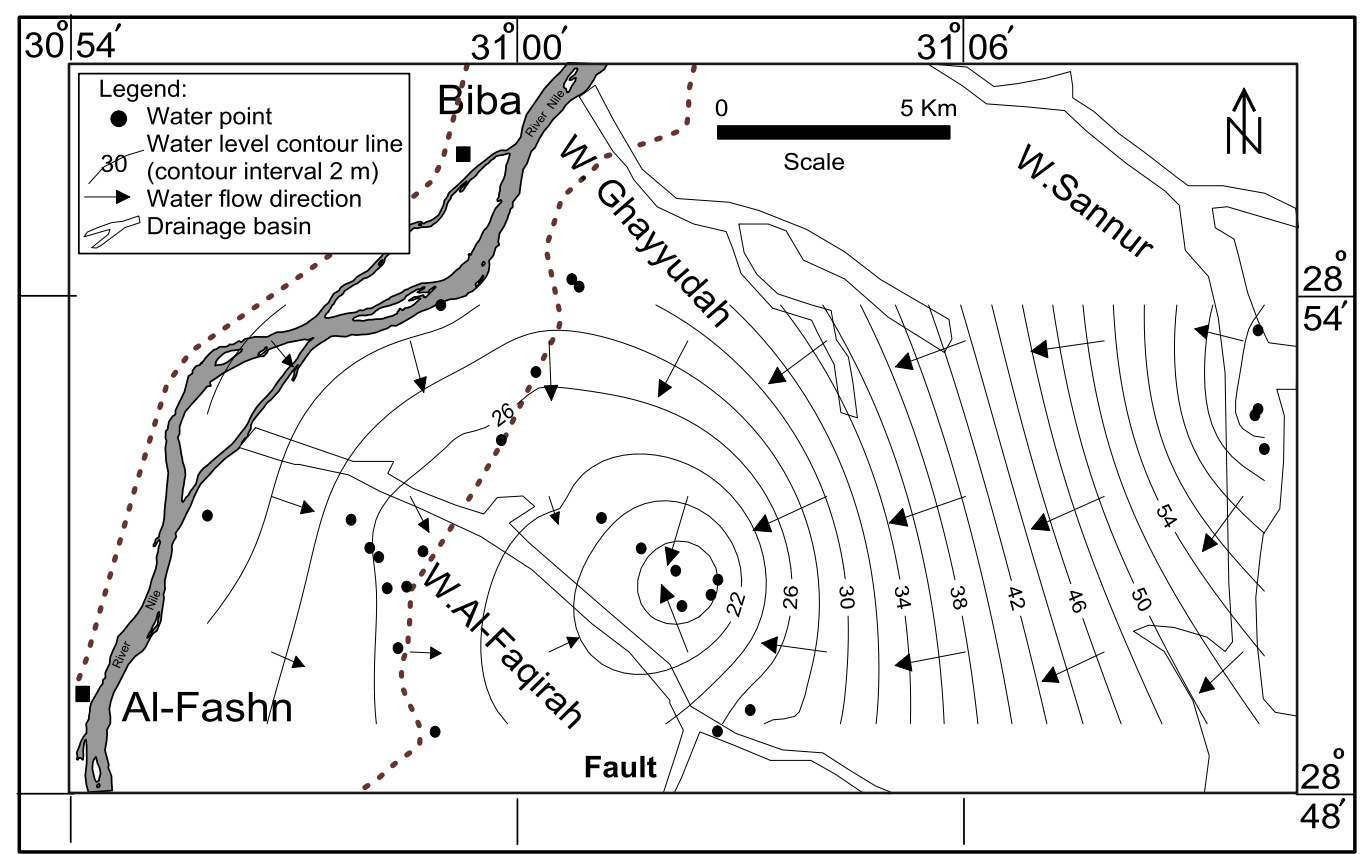

Fig. 8: Water level contour map of Biba - El-Fashn area (2014).
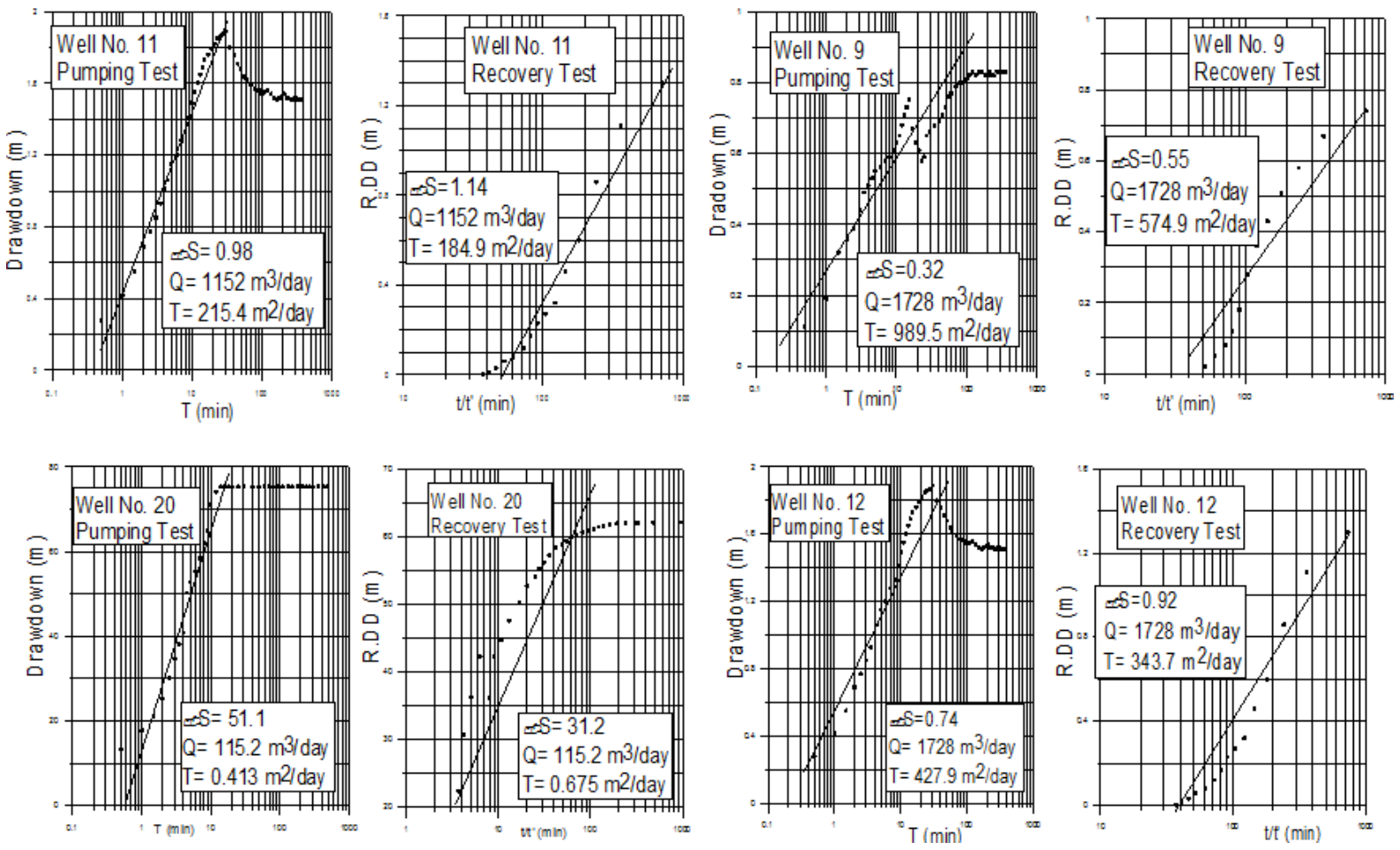

Fig. 9: Pumping and recovery tests analysis, Biba - El-Fashn wells, Middle Eocene aquifers.

Table 2: Aquifer potentialities classification and classes for Middle Eocene aquifers ${ }^{[15]}$.

\begin{tabular}{|c|c|c|}
\hline Aquifer potentiality classes & Transmissivity (m2/day) & Studied Transmissivity of Middle Eocene aquifers \\
\hline High & $>500$ & 782.2 (Well No. 9) \\
\hline Moderate & $50-500$ & 200.15 (Well No. 11), 385.8 (Well No. 20) \\
\hline Low & $5-50$ & 0.544 (Well No. 20) \\
\hline Very low & $0.5-5$ & \\
\hline Negligible & $<0.5$ & \\
\hline
\end{tabular}


Hydrochemical characteristics

Twenty five groundwater samples representing the Middle Eocene fractured water bearing formations aquifers were collected and chemically analyzed for major cations and anions (Tables 3 and 4 ). The chemical characteristics of the groundwater are discussed.

Table 3: Chemical analysis of data of groundwater samples of Middle Eocene aquifers (2014).

\begin{tabular}{|c|c|c|c|c|c|c|c|c|c|c|c|c|}
\hline $\begin{array}{l}\text { Well } \\
\text { No. }\end{array}$ & $\begin{array}{c}\text { E.C } \\
\text { mMhos/cm }\end{array}$ & pH & $\begin{array}{c}\text { TDS } \\
(\mathrm{mg} / \mathrm{l})\end{array}$ & $\begin{array}{c}\mathrm{Ca}^{++} \\
(\mathrm{mg} / \mathrm{l})\end{array}$ & $\begin{array}{c}\mathrm{Mg}^{++} \\
(\mathrm{mg} / \mathrm{l})\end{array}$ & $\begin{array}{c}\mathrm{Na}^{+} \\
(\mathrm{mg} / \mathrm{l})\end{array}$ & $\begin{array}{c}\mathbf{K}^{+} \\
(\mathbf{m g} / \mathbf{l})\end{array}$ & $\begin{array}{l}\mathrm{CO}_{3}^{--} \\
(\mathrm{mg} / \mathrm{l})\end{array}$ & $\begin{array}{r}\mathrm{HCO}_{3}^{-} \\
(\mathrm{mg} / \mathrm{l})\end{array}$ & $\begin{array}{l}\mathrm{SO}_{4}^{--} \\
(\mathrm{mg} / \mathrm{l})\end{array}$ & $\begin{array}{c}\mathrm{Cl}^{-} \\
(\mathrm{mg} / \mathrm{l})\end{array}$ & SAR \\
\hline 1 & 5710 & 6.98 & 3663.20 & 307.20 & 233.28 & 675 & 12.50 & 43.09 & 219.05 & 680.60 & 1602.00 & 7.065 \\
\hline 2 & 9280 & 6.93 & 5932.00 & 364.80 & 93.31 & 1690 & 12.00 & 36.94 & 118.91 & 1050.00 & 2625.50 & 20.43 \\
\hline 3 & 3640 & 7.03 & 2340.75 & 326.40 & 221.62 & 160 & 10.50 & 24.62 & 194.02 & 610.60 & 890.00 & 1.675 \\
\hline 4 & 6170 & 6.95 & 3946.69 & 345.60 & 256.61 & 750 & 8.50 & 24.62 & 162.72 & 300.00 & 2180.00 & 7.447 \\
\hline 5 & 3210 & 7.31 & 2056.66 & 172.80 & 69.98 & 465 & 7.50 & 24.62 & 150.21 & 450.80 & 790.85 & 7.541 \\
\hline 6 & 2758 & 7.45 & 1748.89 & 134.40 & 78.20 & 380 & 4.50 & 12.31 & 143.95 & 400.00 & 667.50 & 6.447 \\
\hline 7 & 3920 & 8.30 & 2508.80 & 202.20 & 112.20 & 554 & 7.50 & 67.72 & 456.88 & 520.00 & 816.90 & 7.751 \\
\hline 8 & 2263 & 7.47 & 1448.32 & 124.40 & 59.98 & 315 & 5.50 & 30.78 & 125.17 & 325.00 & 525.10 & 5.803 \\
\hline 9 & 3100 & 7.25 & 1984.00 & 153.60 & 93.31 & 425 & 7.00 & 18.47 & 131.43 & 420.00 & 800.00 & 6.673 \\
\hline 10 & 2970 & 7.30 & 1900.80 & 153.60 & 81.65 & 410 & 6.00 & 18.47 & 106.40 & 430.50 & 743.15 & 6.648 \\
\hline 11 & 1429 & 7.08 & 914.56 & 153.60 & 81.65 & 31 & 7.00 & 24.62 & 81.36 & 226.00 & 320.00 & 0.503 \\
\hline 12 & 3290 & 6.99 & 2105.60 & 172.80 & 81.65 & 480 & 7.00 & 135.43 & 112.65 & 400.60 & 765.40 & 7.536 \\
\hline 13 & 2378 & 7.32 & 1521.92 & 153.60 & 81.65 & 285 & 6.00 & 147.74 & 168.98 & 300.00 & 460.60 & 4.621 \\
\hline 14 & 2136 & 7.35 & 1367.04 & 134.40 & 58.32 & 275 & 7.50 & 24.62 & 137.69 & 275.00 & 511.75 & 4.986 \\
\hline 15 & 3230 & 6.82 & 2067.20 & 172.80 & 128.30 & 385 & 11.50 & 36.94 & 143.95 & 440.50 & 830.50 & 5.406 \\
\hline 16 & 1094 & 7.52 & 700.16 & 100.20 & 39.60 & 95 & 7.50 & 43.09 & 112.65 & 130.65 & 230.50 & 2.033 \\
\hline 17 & 899 & 7.60 & 575.36 & 58.50 & 28.60 & 105 & 7.50 & 30.78 & 168.98 & 138.80 & 120.30 & 2.812 \\
\hline 18 & 863 & 7.30 & 552.32 & 50.60 & 35.60 & 95 & 7.00 & 36.94 & 117.80 & 152.00 & 120.00 & 2.502 \\
\hline 19 & 1267 & 7.35 & 810.88 & 90.60 & 41.20 & 138 & 6.00 & 18.47 & 131.43 & 205.00 & 250.00 & 3.017 \\
\hline 20 & 1735 & 7.22 & 1110.40 & 120.50 & 100.60 & 125 & 7.50 & 24.62 & 106.40 & 238.00 & 440.30 & 2.034 \\
\hline 21 & 400 & 7.05 & 256.00 & 50.60 & 11.66 & 27 & 6.00 & 30.65 & 102.30 & 46.60 & 40.05 & 0.889 \\
\hline 22 & 5630 & 7.88 & 3579.00 & 223.00 & 245.00 & 730 & 8.00 & 0.00 & 488.00 & 760.00 & 1369.00 & 8.026 \\
\hline 23 & 7000 & 8.06 & 4581.00 & 282.00 & 248.00 & 1000 & 8.00 & 0.00 & 366.00 & 1100.00 & 1760.00 & 10.47 \\
\hline 24 & 9000 & 7.99 & 5293.50 & 474.00 & 245.00 & 1100 & 12.00 & 0.00 & 427.00 & 765.00 & 2484.00 & 10.22 \\
\hline 25 & 5000 & 8.18 & 3442.50 & 584.00 & 38.00 & 500 & 8.00 & 0.00 & 427.00 & 1440.00 & 659.00 & 5.412 \\
\hline River Nile & 360 & 7.17 & 237.38 & 40.00 & 11.66 & 30 & 5.00 & 12.31 & 100.80 & 43.00 & 45.00 & 0.93 \\
\hline
\end{tabular}

Table 4: Hydrochemical coefficient and hypothetical Salts assemblage of groundwater samples (2014).

\begin{tabular}{|c|c|c|c|c|c|c|c|c|c|c|c|c|}
\hline \multirow{2}{*}{$\begin{array}{l}\text { Well } \\
\text { No. }\end{array}$} & \multicolumn{3}{|c|}{ Hydrochemical coefficient } & \multicolumn{9}{|c|}{ Hypothetical Salts assemblage } \\
\hline & $\mathrm{Na} / \mathrm{Cl}$ & $\mathrm{SO}_{4} / \mathrm{Cl}$ & $\mathrm{Ca} / \mathrm{Mg}$ & $\mathrm{NaCl}$ & $\mathrm{Na}_{2} \mathrm{SO}_{4}$ & $\mathrm{NaHCO}_{3}$ & $\mathrm{MgCl}_{2}$ & $\mathrm{MgSO}_{4}$ & $\mathrm{Mg}\left(\mathrm{HCO}_{3}\right)_{2}$ & $\mathrm{CaCl}_{2}$ & $\mathrm{CaSo}_{4}$ & $\mathrm{Ca}\left(\mathrm{HCO}_{3}\right)_{2}$ \\
\hline 1 & 0.67 & 0.3 & 0.90 & 46.23 & 0 & 0 & 23.95 & 5.94 & 0 & 0 & 16.08 & 7.81 \\
\hline 2 & 1 & 0.3 & 2.37 & 74.03 & 0 & 0 & 0.69 & 7.01 & 0 & 0 & 15.06 & 3.21 \\
\hline 3 & 0.29 & 0.5 & 0.89 & 17.31 & 0 & 0 & 42.72 & 0.95 & 0 & 0 & 29.45 & 9.57 \\
\hline 4 & 0.53 & 0.1 & 0.81 & 46.12 & 0 & 0 & 29.65 & 0 & 0 & 10.5 & 8.77 & 4.90 \\
\hline 5 & 0.91 & 0.4 & 1.50 & 58.67 & 0 & 0 & 5.11 & 11.44 & 0 & 0 & 15.40 & 9.39 \\
\hline 6 & 0.88 & 0.4 & 1.04 & 55.88 & 0 & 0 & 7.03 & 14.57 & 0 & 0 & 13.27 & 9.26 \\
\hline 7 & 1.05 & 0.5 & 1.09 & 52.83 & 2.87 & 0 & 0 & 21.17 & 0 & 0 & 0.8 & 22.35 \\
\hline 8 & 0.93 & 0.5 & 1.26 & 55.40 & 0 & 0 & 4.67 & 15.08 & 0 & 0 & 12.37 & 12.48 \\
\hline 9 & 0.83 & 0.4 & 1.0 & 54.88 & 0 & 0 & 11.33 & 11.25 & 0 & 0 & 14.41 & 8.13 \\
\hline 10 & 0.86 & 0.4 & 1.14 & 55.56 & 0 & 0 & 9.36 & 11.39 & 0 & 0 & 16.38 & 7.31 \\
\hline 11 & 0.17 & 0.5 & 1.14 & 46.08 & 0 & 0 & 13.19 & 7.05 & 0 & 0 & 17.96 & 15.72 \\
\hline 12 & 0.98 & 0.4 & 1.28 & 57.85 & 0 & 0 & 1.64 & 16.82 & 0 & 0 & 6.17 & 17.53 \\
\hline 13 & 0.97 & 0.5 & 1.14 & 46.60 & 0 & 0 & 1.64 & 23.19 & 0.10 & 0 & 0 & 28.47 \\
\hline 14 & 0.84 & 0.4 & 1.40 & 51.37 & 0 & 0 & 10.75 & 9.53 & 0 & 0 & 15.11 & 13.25 \\
\hline 15 & 0.72 & 0.4 & 0.82 & 47.05 & 0 & 0 & 17.68 & 11.46 & 0 & 0 & 13.89 & 9.923 \\
\hline 16 & 0.67 & 0.4 & 1.54 & 34.36 & 0 & 0 & 17.63 & 8.26 & 0 & 0 & 13.49 & 26.26 \\
\hline 17 & 1.40 & 0.9 & 1.24 & 33.66 & 13.8 & 0 & 0 & 14.9 & 8.55 & 0 & 0 & 29.11 \\
\hline 18 & 1.27 & 0.9 & 0.86 & 34.85 & 9.3 & 0 & 0 & 23.29 & 6.7 & 0 & 0 & 25.86 \\
\hline 19 & 0.87 & 0.6 & 1.33 & 43.76 & 0 & 0 & 6.29 & 17.81 & 0 & 0 & 12.49 & 19.66 \\
\hline 20 & 0.45 & 0.4 & 0.73 & 28.26 & 0 & 0 & 34.02 & 7.52 & 0 & 0 & 17.33 & 12.86 \\
\hline 21 & 1.18 & 0.9 & 2.63 & 23.54 & 4.05 & 0 & 0 & 16.17 & 3.76 & 0 & 0 & 52.48 \\
\hline 22 & 0.83 & 0.4 & 0.55 & 50.52 & 0 & 0 & 11.31 & 20.56 & 0 & 0 & 4.79 & 12.81 \\
\hline 23 & 0.88 & 0.5 & 0.69 & 55.9 & 0 & 0 & 7.30 & 18.80 & 0 & 0 & 10.36 & 7.64 \\
\hline 24 & 0.69 & 0.2 & 1.17 & 52.35 & 0 & 0 & 21.92 & 0.004 & 0 & 1.07 & 17.13 & 7.53 \\
\hline 25 & 1.18 & 1.6 & 9.32 & 33.45 & 7.03 & 0 & 5.76 & 0.004 & 0 & 0 & 41.17 & 12.6 \\
\hline R. Nile & 1.13 & 0.71 & 2.1 & 30.02 & 2.63 & 0 & 0 & 18.55 & 3.31 & 0 & 0.00 & 45.49 \\
\hline
\end{tabular}




\section{Hydrochemical Composition}

The hydrochemical composition of the recorded groundwater is discussed through the total salinity. According to ${ }^{[16]}$ classification (Table 5), nearly all groundwater samples of the studied aquifer appear in the fresh to brackish water classes. The increase of salinity of the groundwater of the studied aquifer is attributed to the presence of shale beds within the water bearing formations.

\section{Hydrogeochemical Classification}

The recorded groundwater samples are hydrogeochemically classified to indicate mixing, leaching, and other chemical processes which took place during the circulation of water.

Schoeller,s diagram; permits the cations and anions to be represented on a single diagram, where major trends can be easily discerned ${ }^{[17]}$. The studied groundwater samples reflect the following results (Fig. 10):

-The following are the orders of dominance of cations and anions:-

$1-\mathrm{Na}^{+}>\mathrm{Ca}^{++}\left(\mathrm{Mg}^{++}\right)>\mathrm{Mg}^{++}\left(\mathrm{Ca}^{++}\right)$and $\mathrm{Cl}^{-}>\mathrm{SO}^{-}\left(\mathrm{HCO}^{-}\right)>$ $\mathrm{HCO}_{3}{ }^{-}\left(\mathrm{SO}^{-}\right)$wells Nos.1, 2, 4, 5, 6, 7, 8, 9, 10, 12, 13, $14,15,17,18,19,22,23$ and 24

$2-\mathrm{Ca}^{++}>\mathrm{Na}^{+}\left(\mathrm{Mg}^{++}\right)>\mathrm{Mg}^{++}\left(\mathrm{Na}^{+}\right)$and $\mathrm{Cl}^{-}>\mathrm{SO}_{4}^{-}\left(\mathrm{HCO}_{3}\right)>$ $\mathrm{HCO}_{3}{ }^{-}\left(\mathrm{SO}_{4}{ }^{-}\right)$well Nos. 3, 11, 16, 20 and 25
3- $\mathrm{Ca}^{++}>\mathrm{Na}^{+}>\mathrm{Mg}^{++}$and $\mathrm{HCO}_{3}{ }^{-}>\mathrm{Cl}^{-}>\mathrm{SO}_{4}{ }^{-}$wells Nos. 21 and River Nile

It is noticed that most of the groundwater samples reveal the dominance of sodium and chloride reflecting the cation exchange processes. On the other hand, the anions of most of the water samples have advanced stage of metasomatism $\left(\mathrm{Cl}>\mathrm{SO}_{4}>\mathrm{HCO}_{3}\right)$ and some of them have the orders $\mathrm{Cl}^{-}>\mathrm{HCO}_{3}{ }^{-}>\mathrm{SO}_{4}^{--} \& \quad \mathrm{HCO}_{3}^{-}>\mathrm{Cl}^{-}>\quad \mathrm{SO}_{4}^{-}$ reflecting the impact of meteoric and Nile water origin.

-The groundwater reveals the salt assemblages as following (Table 4):

1- $\mathrm{NaCl}, \mathrm{MgCl}_{2}, \mathrm{CaSO}_{4}, \mathrm{Ca}\left(\mathrm{HCO}_{3}\right)_{2}$ and $\mathrm{MgSO}_{4}$.well Nos. 1, 2, 3, 4, 5, 6, 8, 9, 10,11, 12, 13, 14, 15, 16, 19, 20, 22, 23 and 24

2- $\mathrm{NaCl}, \mathrm{Ca}\left(\mathrm{HCO}_{3}\right)_{2}, \mathrm{MgSO}_{4}, \mathrm{Na}_{2} \mathrm{SO}_{4}$ and $\mathrm{CaSO}_{4}$. Well No. 7, 17, 18 and 25

3- $\mathrm{Ca}\left(\mathrm{HCO}_{3}\right)_{2}, \quad \mathrm{NaCl}, \quad \mathrm{MgSO}_{4}, \quad \mathrm{Mg}\left(\mathrm{HCO}_{3}\right)_{2}, \quad$ and $\mathrm{NaHCO}_{3}$. wells No 21 and River Nile

Salt assemblages reflect a very complicated geochemical processes as well as the influence of the ion exchange, which result in the dominance of the first group of salt assemblage in most of the studied water samples. The water type varies between $\mathrm{Cl}-\mathrm{Na}, \mathrm{Cl}-\mathrm{Mg}$ and $\mathrm{HCO}_{3}-\mathrm{Ca}$. However the most dominant is $\mathrm{Cl}-\mathrm{Na}$ reflecting the impact of marine and terrestrial sediments beside meteoric water.

Table 5: Water types based on total salinity (TDS in mg/l) ${ }^{[16]}$.

\begin{tabular}{|l|l|}
\hline Water type & Total dissolved solids (mg/l) \\
\hline Fresh & $0-1000$ \\
\hline Brackish & $1000-10,000$ \\
\hline Saline & $10,000-100,000$ \\
\hline Brine & $>100,000$ \\
\hline
\end{tabular}
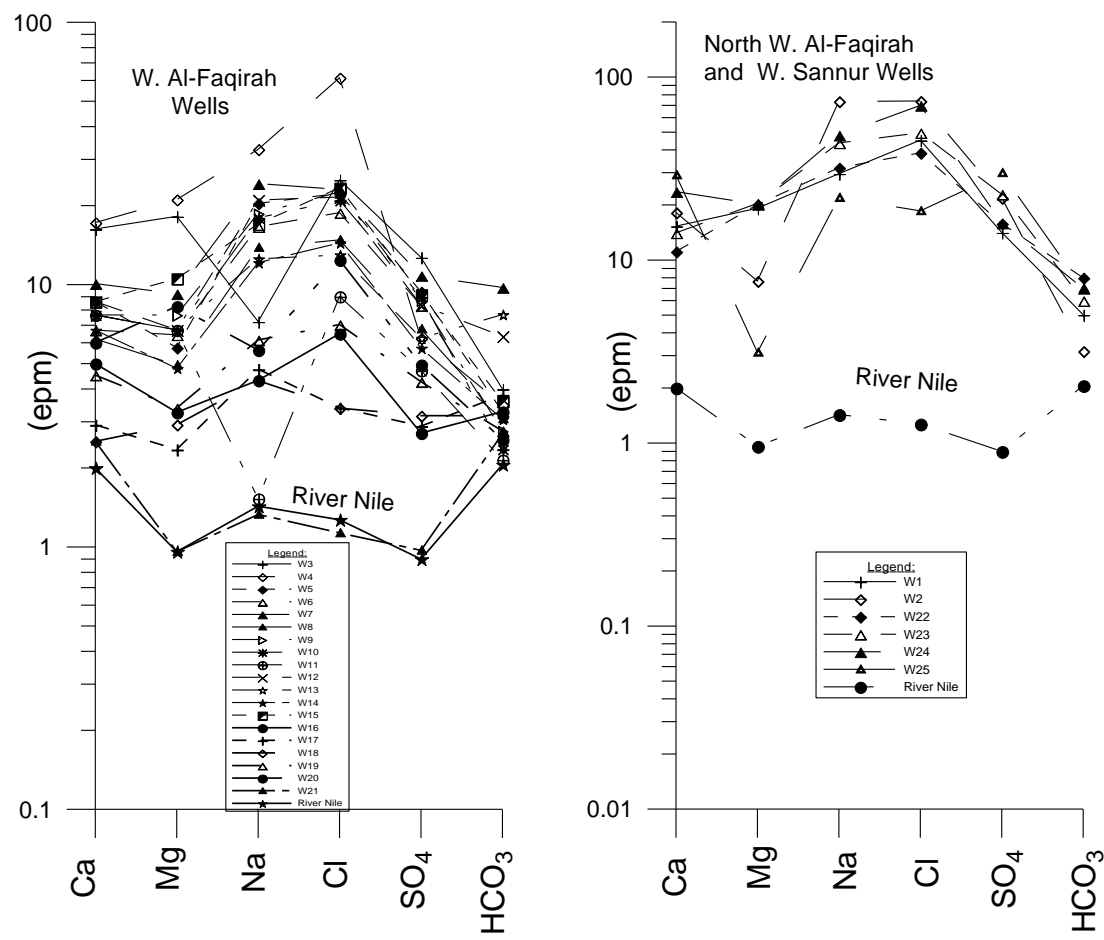

Fig. 10: Schoeller diagram for hydrogeochemical classification of groundwater. 
Trilinear diagram ${ }^{[18]}$ : From the trilinear diagram of the investigated groundwater samples (Fig. 11). It is clear that all samples appear in the upper triangle of the diamond field reflecting the secondary salinity where $\left(\mathrm{SO} 4^{-}+\mathrm{Cl}^{-}\right)$exceeds $\left(\mathrm{Na}^{+}+\mathrm{K}^{+}\right)$and the characteristic water type are $\mathrm{Na}^{+}, \mathrm{Ca}^{+}$and $\mathrm{Mg}^{++}$chlorides and sulphate. This is mainly due to the leaching process of carbonates and shale which contains gypsum and halite.

\section{Quality evaluation for different uses}

One of the main goals of the present study is the evaluation of groundwater quality for drinking and irrigation purposes. This is based on the results of chemical analysis of 25 groundwater samples (Table 3) and the correlation of these results with the international standards of different purposes as follows:

\section{1-Evaluation for drinking purposes}

The water used for drinking should be colorless and free as possible from turbidity and total suspended matter. The chemical analysis of groundwater samples and according to the standard limits given by ${ }^{[19]}$, the salinity contents of all the studied groundwater samples are over the permissible limits for drinking water (1500 mg/l) except wells Nos. 2, 11 and 14 and wells Nos. 16, 21 inclusive (Table 3).

\section{2-Evaluation for irrigation}

The method for evaluating the groundwater for irrigation [20] consists of a plot of the specific conductivity in (micromhos/cm) which is a function of the (TDS) against the Sodium Adsorption Ratio (SAR). Based on the measured EC and the calculated values of SAR the studied groundwater samples are plotted on the diagram
(Fig. 12). It reveals that only eight groundwater samples (Nos. 3, 11 and samples Nos. 16, 21 inclusive) appear in the good water class for irrigation and ten groundwater samples (Nos. 5, 6, 7, 8, 9, 10, 12, 13, 14 and 15) appear in the moderate and intermediate water class for irrigation. On the other hand the other water samples are unsuitable for irrigation.

\section{Concolution}

The water bearing formations in Biba-El Fashn area are El Fashn and Qarara Formations of the Middle Eocene. The groundwater are recorded at depths ranged from $6 \mathrm{~m}$ (west) to $82.2 \mathrm{~m}$ (east) and their salinities are ranged from $256 \mathrm{mg} / \mathrm{l}$ (west) to $5932 \mathrm{mg} / \mathrm{l}$ (east).

Transmissivity values are ranged from $782.5 \mathrm{~m} 2 /$ day (in the western part of the study area) to $0.55 \mathrm{~m} 2 /$ day (in the eastern part). Aquifer potentialities are ranged from high to very low potentiality. The variation in transmissivity and potentiality are attributed mainly to the fractures density. Groundwater is recharged from Nile water of the irrigation canals in the western part of the study area and from the occasional shores rain in the eastern one.

\section{Recommendations}

In the light of the conclusion, the following are recommended:

1) Geophysical well logging of Middle Eocene fractured limestone especially caliper log must be done in order to indicate the intensities of cavities and fracture in subsurface.

2) Drill a test well of about $400 \mathrm{~m}$ depth in the eastern part of the study area to penetrate and check the hydrogeological potentialities of the lower part of Qarara Formation Magagha Formation below.

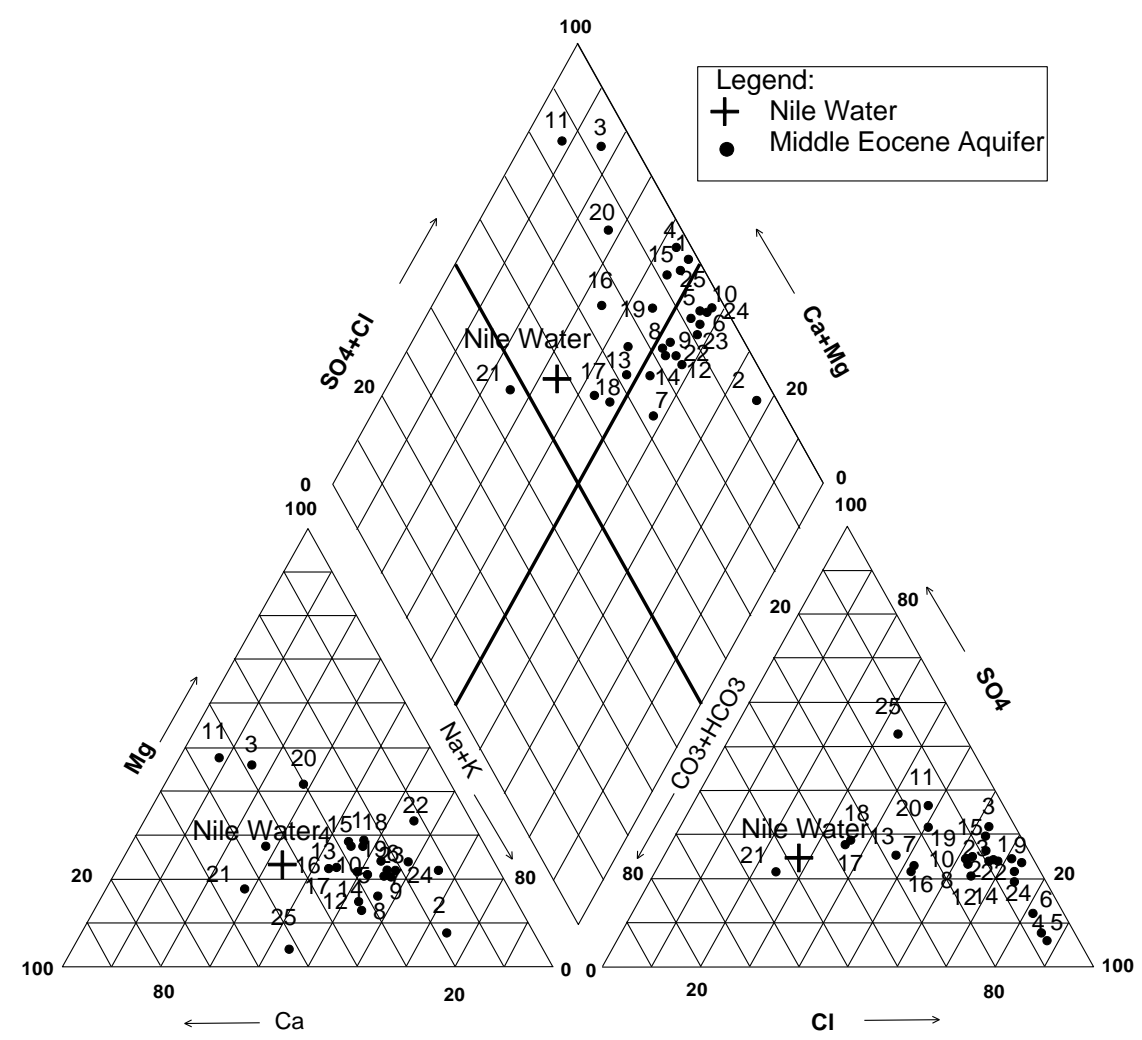

Fig. 11: Hydrogeochemical classification of groundwater using Piper trilinear diagram 


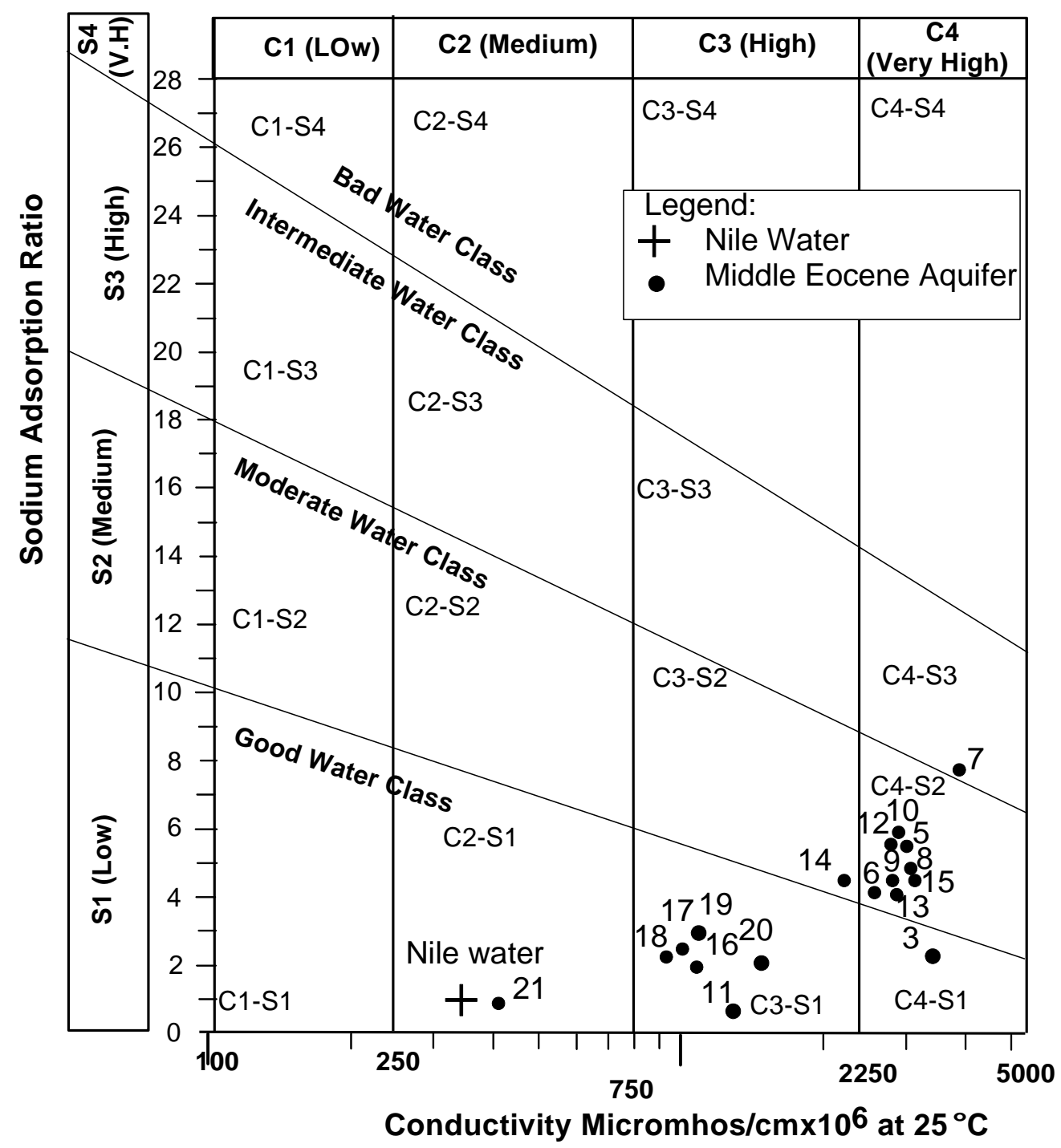

Fig. 12: Evaluation of the groundwater samples for irrigation ${ }^{[20]}$

\section{References}

1) CONOCO (1987). Geologic map (Scale 1: 500,000) Beni Suef Chart.

2) Bishay, Y. (1966). Studies on the large foraminifera of the Eocene, the Nile Valley between Assiout and Cairo. Ph.D. Thesis, Fac. Sci., Alex. Univ., Egypt, $244 \mathrm{p}$.

3) Abdel-Magged, G. M. (1998). Hydrogeological and hydrogeochemical studies of the Nile Valley area, Beni-Suef governorate, Egypt. M.Sc. Thesis, Fac. Sci., Cairo Univ., Egypt, 210 p.

4) Omara, S., Khalifa, H. and Yousef, M. (1978). Contribution to the geology of the area to the southwest of Beni-Suef, Egypt. Bull. Fac. Assiout Univ., Assiout, Egypt, 2:201-226.

5) Hassan, M. Y., Isawi, B. and Zaghloul, E. A. (1978). Geology of the area east of Beni-Suef, Eastern Desert, Egypt. Annals of the Geol. Surv., Egypt, VIII:129 - 162.

6) Strougo, A., Haggag, M. A. Y., Fairs, M. and Azab, M. (1984). Eocene statigraphy of the BeniSuef area. Bull. Fac., Sci., Ain-Shams Univ., Fac.,
Sci., Bull., (1982/1983), 24:177 - 192.

7) Korany, E. A. (1980). Peak-runoff calculations and preventing the risk of occasional flooding in Wadi Sannur drainage basin, Eastern Desert, Beni-Suef Governorate, Egypt. Proc. $5^{\text {th }}$ Inter. Congr. Statistic, Computer Sci., Social and Demogr. Res., Ain Shams Univ. Cairo, Egypt, 505-534.

8) El Shamy, I. Z. (1992). Recent recharge and flash flooding opportunities in the Eastern Desert, Egypt. Ann. Geol. Surv. Egypt, XVIII:323-334.

9) Abdel-Magged, G. M. (2002). Hydrogeological and environmental impacts of Agricultural efforts in Beni-Suef area, Nile Valley, Egypt. Ph.D. Thesis, Fac. Sci., Ain-Shams Univ., Egypt, 230 p.

10) Abdel Kawy, W. A. M. and El-Nady, M. A. (2009). Soil erosion assessment using revised universal soil loss equation for selective dry valleys in the Eastern Desert of Egypt. Australian Journal of Basic and Applied Sciences, 3(2):836-843.

11) Shabana, A. R. (2011). The impact of geomorphologic and geologic setting on the water resources and their development in Wadi Sannur, 
Eastern Desert, Egypt. Jornal of geology, 55:33-53.

12) Jacob, C. E. (1950). Flow of groundwater in the engineering hydraulies. John Wiley and sons. New York.

13) Cooper, H. H. and Jacob, C. E. (1946). A generalized graphical method for evaluating formation constants and summarizing well history. Am. Geophys. Union. Trans., 27:526-534.

14) Theis, C. V. (1935). The relation between the lowering of the piezometric surface and the rate and duration of discharge of a well using groundwater storage. Trans. Amer. Geophys. Union. 16:519-524.

15) Gheorghe, A. (1979). Processing and synthesis of hydrogeological data. Abacus press, p. 390.

16) Todd, D. K. (1980). Groundwater hydrology: John
Wiley and Sons, Inc., New York, U.S.A., 535p.

17) Schoeller, H. (1962). Geochemie des eauxsouteraines. Rev. De Français du petrole, 10:230-244.

18) Piper, A. M. (1953). A graphic representation in the geochemical interpretation of groundwater analyses. American Geophysical Union Transactions, 25:914 923.

19) World Health Organization (WHO); (1984). International standards for drinking waters: Geneva World Health Organization, $70 \mathrm{p}$.

20) U. S. Salinity Laboratory Staff (1954). Diagnosis and improvement of saline and alkali soils: U. S. Dept. Agr., handbook No. 60, Washington, D. C., $160 \mathrm{p}$. 